\title{
Thermoregulation in captive broad-snouted caiman (Caiman latirostris)
}

\author{
Luís AB Bassetti ${ }^{1 *}$, Thiago S Marques ${ }^{1}$, Adriana Malvásio², Carlos I Piña ${ }^{3}$ and Luciano M Verdade ${ }^{1}$
}

\begin{abstract}
Background: Crocodilians are ectothermic animals. For this reason, the environmental temperature has substantial effects on their physiology and behavior. The thermoregulatory behavior of these animals involves the selective use of different types of environments. This behavior enables them to reach the temperature level for their metabolic activities. This study aimed to determine the influence of sex, body size, and reproductive stage on the body temperature $\left(T_{b}\right)$ of adult broad-snouted caiman (Caiman latirostris) in captivity. Thermal sensors were surgically implanted in the peritoneal cavity of 16 adult females and 4 adult males and programmed to register $T_{\mathrm{b}}$ hourly during 6 months.

Results: The diel $T_{b}$ pattern of the broad-snouted caiman reflected the variation among the microenvironmental temperatures used by the species (water surface, pool bottom, and ground). The sex of the animals had influence on their $T_{b}$, but body size did not. Reproductive females had higher $T_{b}$ than non-reproductive females during October to early November. It is possible that this difference is a result of the ovulation period of the species. Sick animals appeared to show behavioral fever.

Conclusions: The results of the present study suggest that several factors can affect the $T_{b}$ of adult broad-snouted caiman in captivity. Future studies should focus on the possible effect of thermoregulatory behavior on individuals' growth rate and reproductive performance.
\end{abstract}

Keywords: Crocodilians; Body temperature; Ovulation; Social behavior; Behavioral fever; Reproduction

\section{Background}

Crocodilians are ectothermic animals. For this reason, environmental temperature has substantial effects on their physiology and behavior (Pough et al. 2003). In crocodilians, the main source of heat is solar radiation, but heat conduction from the substrate may also play a fundamental role in behavior (Sajdak and Molina 1992). Body temperature $\left(T_{\mathrm{b}}\right)$ depends on three basic components: behavioral (physical movement to increase or decrease exposure to thermal environmental energy), physiological (organic variations, for example, changes in blood flow), and genetic (medium- and long-term changes, for example, changes in hormone level) (Silva 2000).

\footnotetext{
* Correspondence: luisbassetti@terra.com.br

'Laboratório de Ecologia Isotópica, Centro de Energia Nuclear na Agricultura, Universidade de São Paulo, Caixa Postal 96, Piracicaba, São Paulo 13416-000, Brazil

Full list of author information is available at the end of the article
}

The thermoregulatory behavior of these animals involves different uses of the available environments (Asa et al. 1998; Fincatti and Verdade 2002; Fish and Cosgrove 1987; Seebacher et al. 1999; Verdade et al. 2006). This behavior enables them to reach a $T_{\mathrm{b}}$ for their metabolic activities (Seebacher and Franklin 2005; Smith et al. 1978). In this context, the aquatic environment is extremely important (Brandt and Mazzotti 1990). Caimans (Caiman spp.) are able to maintain their $T_{\mathrm{b}}$ up to $4^{\circ} \mathrm{C}$ above water temperature with only their backs out of the water (Diefenbach 1975a; Fincatti and Verdade 2002). The presence of osteoderms (dense bony plates derived from the skin) in the crocodilians facilitates this process because small holes filled with arterioles can absorb heat and carry it to other parts of the body (Seidel 1979).

$T_{\mathrm{b}}$ can influence diverse ecophysiological aspects of crocodilians (Lang 1987), including growth rate. Food consumption and growth rate were higher in American alligators (Alligator mississippiensis) maintained at $32^{\circ} \mathrm{C}$ than in animals kept at $28^{\circ} \mathrm{C}$ (Staton et al. 1992). Broad-

\section{Springer}


Table 1 Composition of experimental groups

\begin{tabular}{|c|c|c|}
\hline Enclosure & $M / F$ & Individuals \\
\hline \multirow[t]{5}{*}{ ARN1 } & $1: 4$ & USP $123(F)$ \\
\hline & & USP 124 (M) \\
\hline & & USP $126(F)$ \\
\hline & & USP $127(F)$ \\
\hline & & USP $128(F)$ \\
\hline \multirow[t]{5}{*}{ ARN2 } & $1: 4$ & USP 113 (F) \\
\hline & & USP 114 (M) \\
\hline & & USP $116(F)$ \\
\hline & & USP 117 (F) \\
\hline & & USP $121(F)$ \\
\hline \multirow[t]{5}{*}{ ARN3 } & $1: 4$ & USP $115(F)$ \\
\hline & & USP $118(F)$ \\
\hline & & USP $119(\mathrm{~F})$ \\
\hline & & USP 120 (M) \\
\hline & & USP $122(F)$ \\
\hline \multirow[t]{5}{*}{ ARN4 } & $1: 4$ & USP 125 (M) \\
\hline & & USP $129(\mathrm{~F})$ \\
\hline & & USP $130(F)$ \\
\hline & & USP $131(F)$ \\
\hline & & USP 132 (F) \\
\hline
\end{tabular}

$F$, females; $M$, males.

snouted caiman (Caiman latirostris) hatchlings when maintained at $34^{\circ} \mathrm{C}$ showed relatively high values of growth rate and weight gain (Vianna 1995). Pantanal caiman (Caiman crocodilus yacare) hatchlings kept at $32^{\circ} \mathrm{C}$ showed higher growth rates than individuals maintained at $28^{\circ} \mathrm{C}$ (Miranda et al. 1999).

Environmental temperature can also affect food consumption in broad-snouted caiman (Larriera et al. 1990;
Verdade 1992a, b). Seasonal variations in temperature can act directly to change the food consumption in American alligators (Coulson and Hernandez 1983). Furthermore, in crocodilians, the rate of food digestion in the gastrointestinal tract depends on $T_{\mathrm{b}}$ (Diefenbach 1975a, b; Vianna et al. 1995).

Social behavior in crocodilians can directly influence thermoregulatory behavior. Social dominance can be related to habitat use and to the resources available in the habitat (Alcock 1993; Krebs 1985; Krebs and Davis 1991). Sajdak and Molina (1992) report that the presence of dominant animals in one location may make other individuals occupy locations that are less adequate from a thermoregulatory standpoint perspective. A variety of evidence shows that territorial behavior in crocodilians is expressed on the margins of a water body and not necessarily in its interior (Lang 1987, 1989; Verdade 1992b; Verdade et al. 2006). The margins are the area where animals primarily sunbathe (Ayarzaguena 1983; Molina and Sajdak 1993) and spend time during the day (Verdade et al. 2006).

The present study aimed to determine the pattern of $T_{\mathrm{b}}$ variation in adult broad-snouted caiman in captivity and its relationship with sex, body size, and reproductive status. Such information is important for the management of individuals in breeding farms, as well as for the understanding of reproduction in wild individuals.

\section{Methods}

Data were collected in the captive colony of the broadsnouted caiman at the Laboratório de Ecologia Animal of the Universidade de São Paulo (Brazil) between August 2000 and January 2001. The facilities consisted of four $9 \times 10 \mathrm{~m}$ modules, each containing a $4 \times 6 \mathrm{~m}$ pool ( $1 \mathrm{~m}$ deep) and five $2 \times 2 \mathrm{~m}$ nesting areas. The

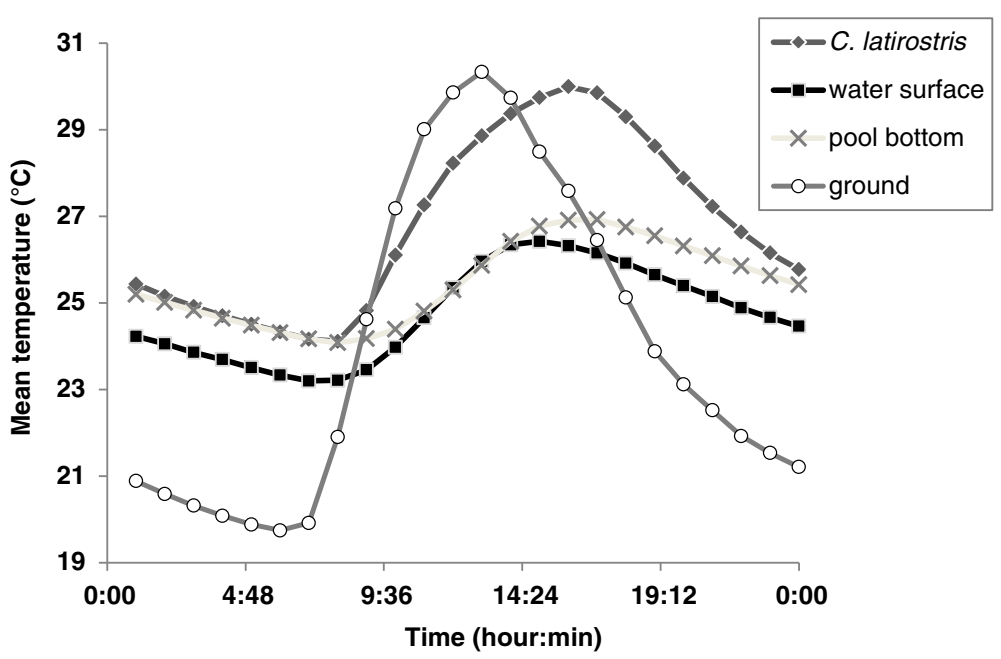

Figure 1 Mean temperature variation of broad-snouted caiman and different microhabitats of the animals' facilities. 
Table 2 Statistical values of the relationship between body temperature and body size in captive adult broad-snouted caiman

\begin{tabular}{|c|c|c|c|c|c|c|}
\hline & \multicolumn{2}{|c|}{ Mean temperature } & \multicolumn{2}{|c|}{ Minimum temperature } & \multicolumn{2}{|c|}{ Maximum temperature } \\
\hline & SVL & Body mass & SVL & Body mass & SVL & Body mass \\
\hline Aug. 10 to 20,2000 & $p=0.325 ; S=1.1 ; r^{2}=6.5 \%$ & $p=0.232 ; S=1.1 ; r^{2}=9.4 \%$ & $p=0.427 ; S=1.2 ; r^{2}=4.3 \%$ & $p=0.427 ; S=1.2 ; r^{2}=4.3 \%$ & $p=0.271 ; S=1 ; r^{2}=8 \%$ & $p=0.271 ; S=1 ; r^{2}=8 \%$ \\
\hline Aug. 21 to 31, 2000 & $p=0.247 ; S=0.7 ; r^{2}=8.8 \%$ & $p=0.460 ; S=0.7 ; r^{2}=3.7 \%$ & $p=0.193 ; S=1.1 ; r^{2}=11 \%$ & $p=0.193 ; S=1.1 ; r^{2}=11 \%$ & $p=0.544 ; S=0.7 ; r^{2}=2.5 \%$ & $p=0.544 ; S=0.7 ; r^{2}=2.5 \%$ \\
\hline Sept. 1 to 10,2000 & $p=0.789 ; S=0.8 ; r^{2}=0.5 \%$ & $p=0.995 ; S=0.8 ; r^{2}=0 \%$ & $p=0.299 ; S=0.2 ; r^{2}=7.2 \%$ & $p=0.299 ; S=0.2 ; r^{2}=7.2 \%$ & $p=0.140 ; S=0.6 ; r^{2}=13.9 \%$ & $p=0.140 ; S=0.6 ; r^{2}=13 \%$ \\
\hline Sept. 11 to 20,2000 & $p=0.373 ; S=0.6 ; r^{2}=5.3 \%$ & $p=0.325 ; S=1.1 ; r^{2}=6.5 \%$ & $p=0.536 ; S=0.4 ; r^{2}=2.6 \%$ & $p=0.536 ; S=0.4 ; r^{2}=2.6 \%$ & $p=0.714 ; S=0.7 ; r^{2}=0.9 \%$ & $p=0.714 ; S=0.7 ; r^{2}=0.9 \%$ \\
\hline Sept. 21 to 30,2000 & $p=0.264 ; S=0.6 ; r^{2}=8.2 \%$ & $p=0.247 ; S=0.7 ; r^{2}=8.8 \%$ & $p=0.858 ; S=0.4 ; r^{2}=0.2 \%$ & $p=0.858 ; S=0.4 ; r^{2}=0.2 \%$ & $p=0.580 ; S=0.9 ; r^{2}=2.1 \%$ & $p=0.580 ; S=0.9 ; r^{2}=2.1 \%$ \\
\hline Oct. 1 to 10,2000 & $p=0.539 ; S=0.6 ; r^{2}=2.6 \%$ & $p=0.789 ; S=0.8 ; r^{2}=0.5 \%$ & $p=0.363 ; S=0.5 ; r^{2}=5.5 \%$ & $p=0.544 ; S=0.5 ; r^{2}=5.5 \%$ & $p=0.473 ; S=0.9 ; r^{2}=3.5 \%$ & $p=0.473 ; S=0.9 ; r^{2}=3.5 \%$ \\
\hline Oct. 11 to 20,2000 & $p=0.278 ; S=0.6 ; r^{2}=7.8 \%$ & $p=0.373 ; S=0.6 ; r^{2}=5.3 \%$ & $p=0.903 ; S=0.8 ; r^{2}=0.1 \%$ & $p=0.903 ; S=0.8 ; r^{2}=0.1 \%$ & $p=0.911 ; S=1 ; r^{2}=0.1 \%$ & $p=0.911 ; S=1 ; r^{2}=0.1 \%$ \\
\hline Oct. 21 to 31,2000 & $p=0.195 ; S=0.7 ; r^{2}=10.9 \%$ & $p=0.264 ; S=0.6 ; r^{2}=8.2 \%$ & $p=0.316 ; S=0.7 ; r^{2}=6.7 \%$ & $p=0.316 ; S=0.7 ; r^{2}=6.7 \%$ & $p=0.059 ; S=0.8 ; r^{2}=21.8 \%$ & $p=0.059 ; S=0.8 ; r^{2}=21 \%$ \\
\hline Nov. 1 to 10,2000 & $p=0.192 ; S=0.9 ; r^{2}=11.1 \%$ & $p=0.539 ; S=0.6 ; r^{2}=2.6 \%$ & $p=0.225 ; S=0.9 ; r^{2}=9.6 \%$ & $p=0.225 ; S=0.9 ; r^{2}=9.6 \%$ & $p=0.295 ; S=1.1 ; r^{2}=7.3 \%$ & $p=0.295 ; S=1.1 ; r^{2}=7.3 \%$ \\
\hline Nov. 11 to 20, 2000 & $p=0.211 ; S=1 ; r^{2}=10.2 \%$ & $p=0.278 ; S=0.6 ; r^{2}=7.8 \%$ & $p=0.858 ; S=1.1 ; r^{2}=0.2 \%$ & $p=0.858 ; S=1.1 ; r^{2}=0.2 \%$ & $p=0.230 ; S=1.2 ; r^{2}=9.5 \%$ & $p=0.230 ; S=1.2 ; r^{2}=9.5 \%$ \\
\hline Nov. 21 to 30,2000 & $p=0.225 ; S=1 ; r^{2}=9.7 \%$ & $p=0.195 ; S=0.7 ; r^{2}=10.9 \%$ & $p=0.625 ; S=1.1 ; r^{2}=1.6 \%$ & $p=0.625 ; S=1.1 ; r^{2}=1.6 \%$ & $p=0.265 ; S=1.4 ; r^{2}=8.2 \%$ & $p=0.265 ; S=1.4 ; r^{2}=8.2 \%$ \\
\hline Dec. 1 to 10,2000 & $p=0.245 ; S=1.1 ; r^{2}=8.9 \%$ & $p=0.192 ; S=0.9 ; r^{2}=11.1 \%$ & $p=0.284 ; S=1.2 ; r^{2}=7.6 \%$ & $p=0.284 ; S=1.2 ; r^{2}=7.6 \%$ & $p=0.333 ; S=1.4 ; r^{2}=6.2 \%$ & $p=0.333 ; S=1.4 ; r^{2}=6.2 \%$ \\
\hline Dec. 11 to 20,2000 & $p=0.251 ; S=1.2 ; r^{2}=8.7 \%$ & $p=0.211 ; S=1 ; r^{2}=10.2 \%$ & $p=0.437 ; S=1.2 ; r^{2}=4.1 \%$ & $p=0.437 ; S=1.2 ; r^{2}=4.1 \%$ & $p=0.471 ; S=1.2 ; r^{2}=3.5 \%$ & $p=0.471 ; S=1.2 ; r^{2}=3.5 \%$ \\
\hline Dec. 21 to 31,2000 & $p=0.258 ; S=1.3 ; r^{2}=8.5 \%$ & $p=0.225 ; S=1 ; r^{2}=9.7 \%$ & $p=0.631 ; S=1.5 ; r^{2}=1.6 \%$ & $p=0.631 ; S=1.5 ; r^{2}=1.6 \%$ & $p=0.999 ; S=1.9 ; r^{2}=0 \%$ & $p=0.999 ; S=1.9 ; r^{2}=0 \%$ \\
\hline Jan. 1 to 10,2001 & $p=0.239 ; S=1.4 ; r^{2}=9.1 \%$ & $p=0.245 ; S=1.1 ; r^{2}=8.9 \%$ & $p=0.441 ; S=1.8 ; r^{2}=4 \%$ & $p=0.441 ; S=1.8 ; r^{2}=4 \%$ & $p=0.817 ; S=1.6 ; r^{2}=0.4 \%$ & $p=0.817 ; S=1.6 ; r^{2}=0.4 \%$ \\
\hline Jan. 11 to 20, 2001 & $p=0.263 ; S=1.5 ; r^{2}=8.3 \%$ & $p=0.251 ; S=1.2 ; r^{2}=8.7 \%$ & $p=0.241 ; S=1.7 ; r^{2}=9 \%$ & $p=0.241 ; S=1.7 ; r^{2}=9 \%$ & $p=0.719 ; S=1.4 ; r^{2}=0.9 \%$ & $p=0.719 ; S=1.4 ; r^{2}=0.9 \%$ \\
\hline Jan. 21 to 31,2001 & $p=0.266 ; S=1.8 ; r^{2}=8.2 \%$ & $p=0.258 ; S=1.3 ; r^{2}=8.5 \%$ & $p=0.300 ; S=2.1 ; r^{2}=7.1 \%$ & $p=0.300 ; S=2.1 ; r^{2}=7.1 \%$ & $p=0.332 ; S=2 ; r^{2}=6.3 \%$ & $p=0.332 ; S=2 ; r^{2}=6.3 \%$ \\
\hline
\end{tabular}



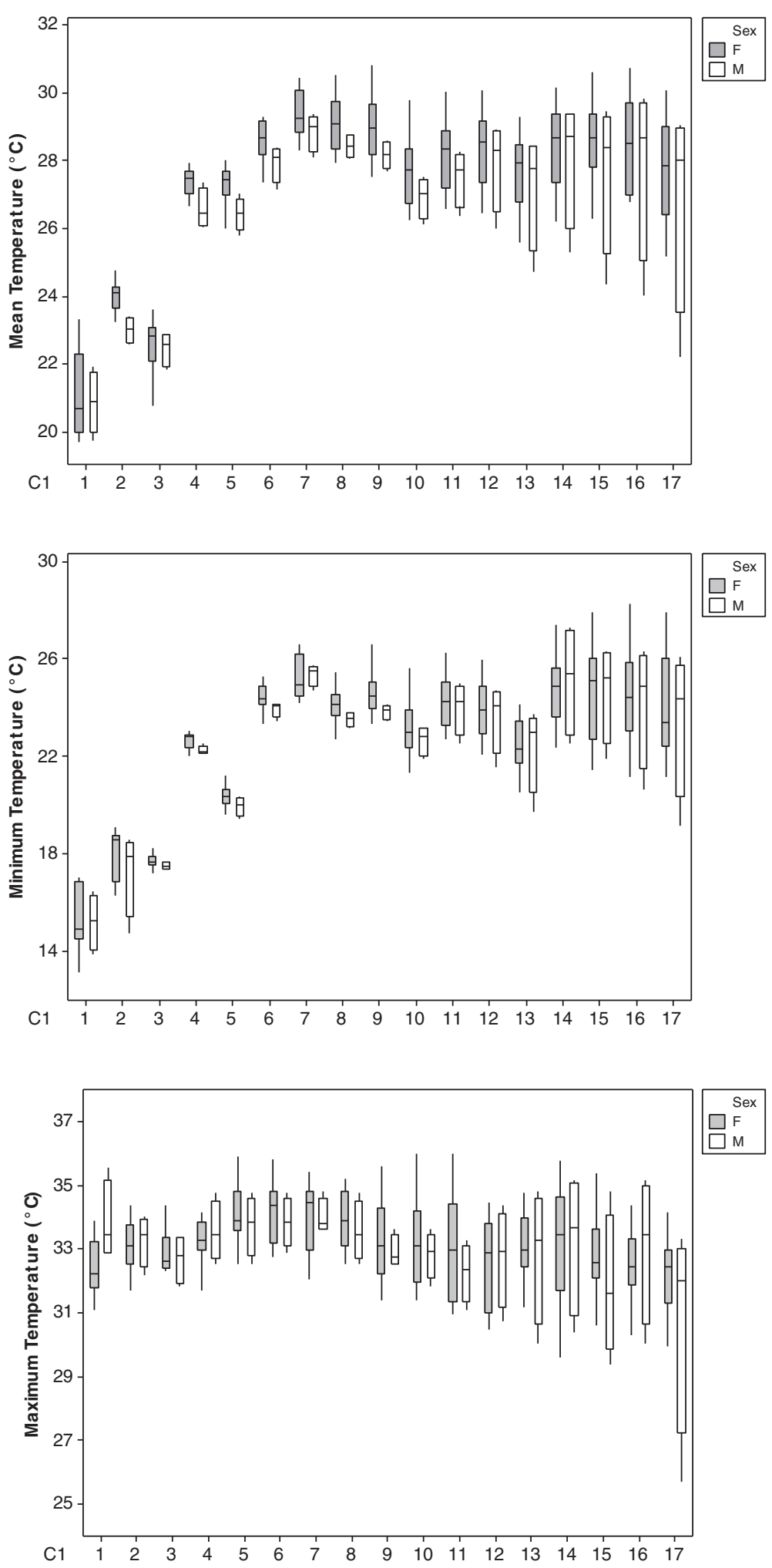

Figure 2 Pattern of body temperature variation between sexes in captive adult broad-snouted caiman. 1 - Aug. 10 to 20, 2000;

2 - Aug. 21 to 31, 2000; 3 - Sept. 1 to 10, 2000; 4 - Sept. 11 to 20, 2000; 5 - Sept. 21 to 30, 2000; 6 - Oct. 1 to 10, 2000; 7 - Oct. 11 to 20, 2000; 8 - Oct. 21 to 31, 2000; 9 - Nov. 1 to 10, 2000; 10 - Nov. 11 to 20, 2000; 11 - Nov. 21 to 30, 2000; 12 - Dec. 1 to 10, 2000; 13 - Dec. 11 to 20, 2000; 14 - Dec. 21 to 31, 2000; 15 - Jan. 1 to 10, 2001; 16 - Jan. 11 to 20, 2001; 17 - Jan. 21 to 31, 2001. 
designs of the nesting areas for crocodilians were initially proposed by Bustard (1975) and adapted by Verdade et al. (1993) for the broad-snouted caiman.

The experimental groups were composed of the founding individuals of the captive colony at the Laboratório de Ecologia Animal, registered in the Regional Studbook for this species in Brazil (Verdade and Kassouf-Perina 1993) and totaling 20 animals (16 females and 4 males; see Table 1). The animals were measured, weighed, marked with interdigital tags, and sexed by visual inspection of the gonads with the help of a human nasal speculum (Allstead and Lang 1995). The animals' diet was maintained at a constant level during the entire experimental period. The diet consisted of a mixture of ground chicken, pork, and fish in equal proportions. The diet was supplied weekly at a level of $7 \%$ of the live mass of the animals (Sarkis-Gonçalves 2000). Nesting females were identified by their parental behavior, namely the construction and protection of the nest (Bustard 1980; Hunt 1987; Widholzer et al. 1986).

Thermal sensors HOBO TBI32-20+50 (Onset Computer Corporation, Bourne, MA, USA) were implanted in the animals. The sensors were covered with non-toxic plastic. They measured $3 \mathrm{~cm}$ in basal diameter and $1.5 \mathrm{~cm}$ in height. They were programmed to record the $T_{\mathrm{b}}$ each hour (precision $\pm 0.1^{\circ} \mathrm{C}$ ) for a period of 180 days. After that period, infiltration could occur, resulting in error in data collection. The thermal sensor was inserted in the body coelomic cavity below the peritoneum as described by Troiano (1991), between the jejunum and ileum, which are of equal size on both the left and right sides of the peritoneal cavity, as described by Merwe and Kotze (1993) for Crocodylus niloticus. Local anesthesia was applied with lidocaine (Eurofarma Laboratórios Ltda, São Paulo, Brazil) (diethylaminoaceto-alpha-2,6xylidide) at a concentration of $2 \mathrm{~g} / 100 \mathrm{ml}$ per regional block. The skin suture was performed with a black nylon monofilament (size 0) accompanied by the use of a topical antibiotic with a chloramphenicol base to prevent bacterial growth. After surgery, the animals were maintained for $24 \mathrm{~h}$ in a dry and cold location. Thermal sensors were also placed in three environments in the crocodilians' facilities: the water surface (4), pool bottom (4), and ground (4). This study was carried out in compliance with the guidelines of the Brazilian Association of Wildlife Veterinary Medicine (ABRAVAS). The methods herein used were previously approved by the Ethics Commission of the University of São Paulo at Piracicaba.

The individuals' mean, maximum, and minimal daily temperatures, at 10-day intervals from August 10 to January 31, 2001, were treated as independent variables and compared among the animals. Sex, size, body mass, reproductive status, and health condition were treated as dependent variables. Student's $t$ test was used to verify possible differences in $T_{\mathrm{b}}$ (mean, maximum, and minimum temperatures) between the sexes and health condition (healthy and sick). Linear regression was applied to verify the relationship between $T_{\mathrm{b}}$ (mean, maximum, and minimum temperatures) and snout-vent length (SVL) and body mass. Analysis of variance (ANOVA) was used to analyze differences in $T_{\mathrm{b}}$ between females ( $n$, non-reproductive female; sf, female laying fertile eggs;

Table 3 Statistical values of comparison of body temperature between sexes in captive adult broad-snouted caiman

\begin{tabular}{lllc}
\hline & Mean temperature & Minimum temperature & Maximum temperature \\
\hline 1 - Aug. 10 to 20,2000 & $t_{1,16}=0.4 ; p=0.681$ & $t_{1,16}=0.4 ; p=0.704$ & $t_{1,16}=-2 ; p=0.129$ \\
2 - Aug. 21 to 31,2000 & $t_{1,16}=3.3 ; p=0.009$ & $t_{1,16}=0.7 ; p=0.527$ & $t_{1,16}=-0.4 ; p=0.673$ \\
3 - Sept. 1 to 10,2000 & $t_{1,16}=0.6 ; p=0.800$ & $t_{1,16}=1.8 ; p=0.092$ & $t_{1,16}=0.5 ; p=0.624$ \\
4 - Sept. 11 to 20,2000 & $t_{1,16}=2.2 ; p=0.089$ & $t_{1,16}=1.8 ; p=0.094$ & $t_{1,16}=-0.5 ; p=0.604$ \\
5 - Sept. 21 to 30,2000 & $t_{1,16}=2.8 ; p=0.038$ & $t_{1,16}=1.8 ; p=0.124$ & $t_{1,16}=0.6 ; p=0.570$ \\
6 - Oct. 1 to 10,2000 & $t_{1,16}=1.9 ; p=0.114$ & $t_{1,16}=2.5 ; p=0.034$ & $t_{1,16}=0.7 ; p=0.512$ \\
7 - Oct. 11 to 20,2000 & $t_{1,16}=1.5 ; p=0.163$ & $t_{1,16}=0.1 ; p=0.878$ & $t_{1,16}=0.1 ; p=0.882$ \\
8 - Oct. 21 to 31,2000 & $t_{1,16}=2.3 ; p=0.037$ & $t_{1,16}=2.4 ; p=0.029$ & $t_{1,16}=0.8 ; p=0.437$ \\
9 - Nov. 1 to 10,2000 & $t_{1,16}=0.04 ; p=0.044$ & $t_{1,16}=2.5 ; p=0.025$ & $t_{1,16}=0.8 ; p=0.415$ \\
10 - Nov. 11 to 20,2000 & $t_{1,16}=1.8 ; p=0.097$ & $t_{1,16}=1 ; p=0.321$ & $t_{1,16}=0.7 ; p=0.465$ \\
11 - Nov. 21 to 30,2000 & $t_{1,16}=1.2 ; p=0.247$ & $t_{1,16}=0.4 ; p=0.681$ & $t_{1,16}=1.2 ; p=0.250$ \\
12 - Dec. 1 to 10,2000 & $t_{1,16}=0.6 ; p=0.562$ & $t_{1,16}=0.3 ; p=0.746$ & $t_{1,16}=-0.2 ; p=0.818$ \\
13 - Dec. 11 to 20,2000 & $t_{1,16}=0.5 ; p=0.609$ & $t_{1,16}=0.1 ; p=0.907$ & $t_{1,16}=0.2 ; p=0.843$ \\
14 - Dec. 21 to 31,2000 & $t_{1,16}=0.3 ; p=0.720$ & $t_{1,16}=-0.3 ; p=0.774$ & $t_{1,16}=-0.08 ; p=0.943$ \\
15 - Jan. 1 to 10,2001 & $t_{1,16}=0.5 ; p=0.623$ & $t_{1,16}=-0.4 ; p=0.670$ & $t_{1,16}=0.6 ; p=0.585$ \\
16 - Jan. 11 to 20,2001 & $t_{1,16}=0.4 ; p=0.664$ & $t_{1,16}=0.2 ; p=0.818$ & $t_{1,16}=-0.3 ; p=0.740$ \\
17 - Jan. 21 to 31,2001 & $t_{1,16}=0.4 ; p=0.671$ & & $t_{1,16}=0.6 ; p=0.545$ \\
\hline
\end{tabular}



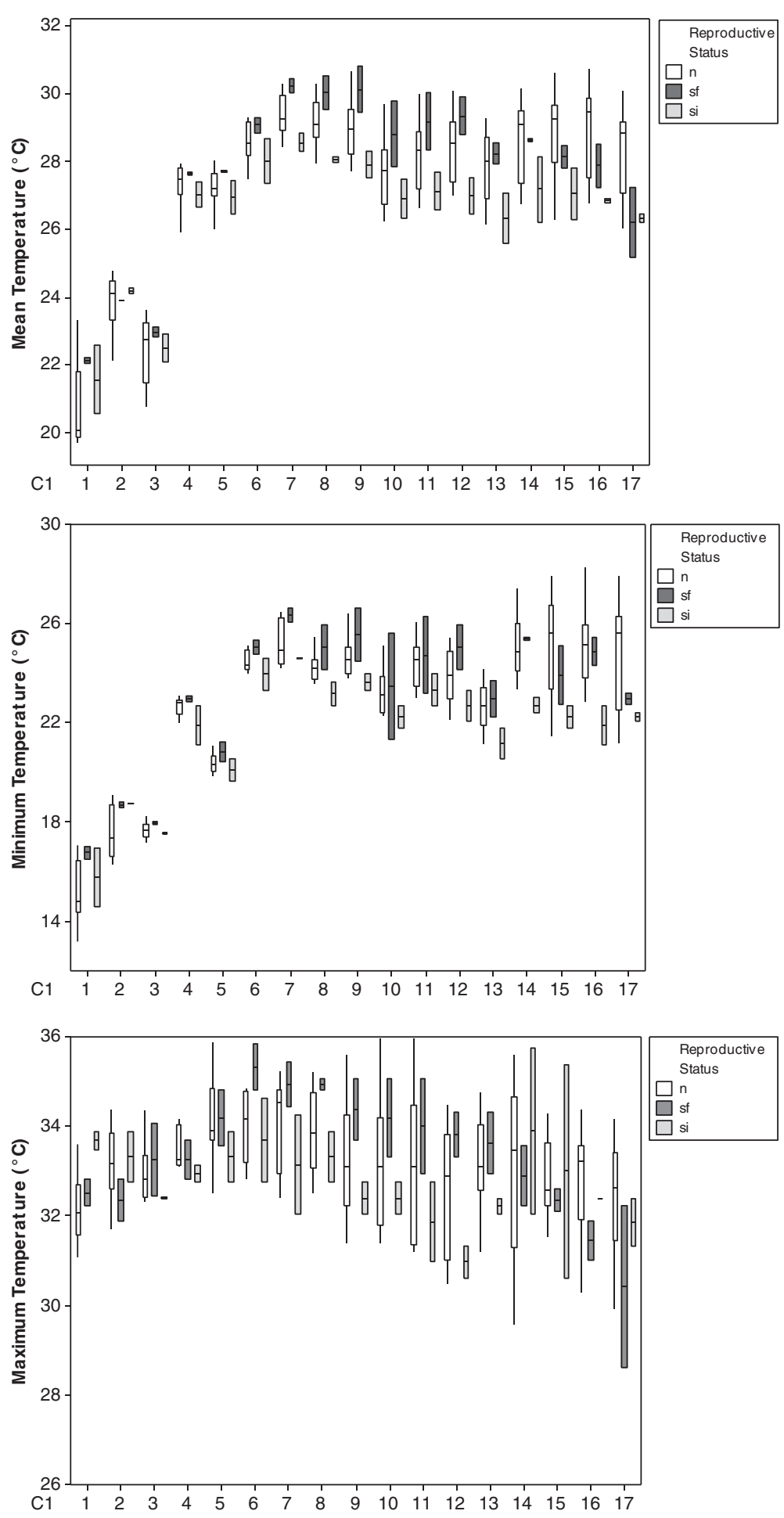

Figure 3 Comparison of body temperature among female captive adult broad-snouted caimans. $n$, non-reproductive female; sf, female laying fertile eggs; si, female laying infertile eggs. 1 - Aug. 10 to 20, 2000; 2 - Aug. 21 to 31, 2000; 3 - Sept. 1 to 10, 2000; 4 - Sept. 11 to 20, 2000; 5 - Sept. 21 to 30, 2000; 6 - Oct. 1 to 10, 2000; 7 - Oct. 11 to 20, 2000; 8 - Oct. 21 to 31, 2000; 9 - Nov. 1 to 10, 2000; 10 - Nov. 11 to 20, 2000; 11 - Nov. 21 to 30, 2000; 12 - Dec. 1 to 10, 2000; 13 - Dec. 11 to 20, 2000; 14 - Dec. 21 to 31, 2000; 15 - Jan. 1 to 10, 2001; 16 - Jan. 11 to 20, 2001; 17 - Jan. 21 to $31,2001$. 
si, female laying infertile eggs). A Tukey HSD test was used to verify possible differences between these treatments. All the analyses were performed in MINITAB 13 (Minitab 2000).

\section{Results}

The animals showed a clear diel variation in $T_{\mathrm{b}}$ during the study period (August 2000 through January 2001), with a minimum temperature of $17^{\circ} \mathrm{C}$ to $23^{\circ} \mathrm{C}$ in the morning (0900 to 1000 hours) and a maximum temperature of \% $32^{\circ} \mathrm{C}$ to $35^{\circ} \mathrm{C}$ in the afternoon (1400 to 1700 hours). This pattern coincides with temperature variation among the different microhabitats of the animals' facilities (water surface, pool bottom, and ground) selectively used by the animals during the day (Figure 1). The water temperature varied from approximately $21^{\circ} \mathrm{C}$ at $09: 00$ hours to $29^{\circ} \mathrm{C}$ at $14: 30$ hours at the surface and from $22.5^{\circ} \mathrm{C}$ at 08:30 hours to $30^{\circ} \mathrm{C}$ at $16: 00$ hours at a depth of $100 \mathrm{~cm}$. The air temperature varied from $17^{\circ} \mathrm{C}$ at $07: 00$ hours to $38^{\circ} \mathrm{C}$ at 14:00 hours at the ground level by the pool margin.

No relationship was found between body mass and snoutvent length (body mass 23.9 to $64.8 \mathrm{~kg}$, snout-vent length 85 to $123 \mathrm{~cm}$; Table 2) and $T_{\mathrm{b}}$ (mean, minimum, and maximum temperatures) of broad-snouted caiman. However, females presented a higher minimum temperature than males from October to early November (Figure 2; Table 3). In addition, reproductive females (i.e., those that laid fertile eggs) had higher $T_{\mathrm{b}}$ than those that laid infertile eggs in the same period (Figure 3; Table 4).

Two females died during the sampling period. These animals presented symptoms of infection and had relatively higher minimum $T_{\mathrm{b}}$ than healthy animals (minimum temperature - healthy: $24.2^{\circ} \mathrm{C} \pm 1.8^{\circ} \mathrm{C}$, sick: $27.4^{\circ} \mathrm{C} \pm 0.6^{\circ} \mathrm{C}$, $t_{1,18}=5.1 ; p=0.014$; mean temperature - healthy: $28.1^{\circ} \mathrm{C} \pm$ $1.4^{\circ} \mathrm{C}$, sick: $30.1^{\circ} \mathrm{C} \pm 0.6^{\circ} \mathrm{C}, t_{1,18}=3.2 ; p=0.082$; maximum temperature- healthy: $32.4^{\circ} \mathrm{C} \pm 1.6^{\circ} \mathrm{C}$, sick: $33.4^{\circ} \mathrm{C} \pm 1.2^{\circ} \mathrm{C}$, $\left.t_{1,18}=1 ; p=0.473\right)$. Both died before the end of the study.

\section{Discussion}

The diel $T_{\mathrm{b}}$ variation of the broad-snouted caiman reflects the thermal variation in the environment used by the species (the water surface, pool bottom, and ground). The ground showed a wide temperature range in comparison to the other environments, followed by the water surface and the pool bottom (Figure 1). These observations show that the available environments provided a wide spectrum of temperatures to be exploited by the animals to thermoregulate. Broad-snouted caiman hatchlings in greenhouses move through the environment during the day, choosing the most suitable temperatures available in the different environments (Verdade et al. 1994). A similar pattern has been described for the American alligator (Lang 1987).

Most of the animals were found in the pool during the morning, but moved out of the water to sunbathe during the hottest hours of the day. This behavioral thermoregulation by moving in and out of the water is consistent with the previous studies for the same species (Molina and Sajdak 1993; Verdade et al. 2006) and for the Nile crocodile (C. niloticus) (Downs et al. 2008).

In nature, female crocodilians can be more sedentary than males (Goodwin and Marion 1979) and, consequently,

\section{Table 4 Statistical values of comparison of body temperature among female captive adult broad-snouted caimans}

\begin{tabular}{llll}
\hline & Mean temperature & Minimum temperature & Maximum temperature \\
\hline 1 - Aug. 10 to 20,2000 & $F_{2,16}=0.8 ; p=0.477$ & $F_{2,16}=1.9 ; p=0.172$ & $F_{2,16}=4.3 ; p=0.025$ \\
2 - Aug. 21 to 31,2000 & $F_{2,16}=1.9 ; p=0.171$ & $F_{2,16}=1.1 ; p=0.382$ & $F_{2,16}=0.7 ; p=0.561$ \\
3 - Sept. 1 to 10,2000 & $F_{2,16}=1.9 ; p=0.900$ & $F_{2,16}=1.3 ; p=0.300$ & $F_{2,16}=0.6 ; p=0.625$ \\
4 - Sept. 11 to 20,2000 & $F_{2,16}=2 ; p=0.158$ & $F_{2,16}=2.9 ; p=0.074$ & $F_{2,16}=0.3 ; p=0.827$ \\
5 - Sept. 21 to 30,2000 & $F_{2,16}=3 ; p=0.069$ & $F_{2,16}=2.1 ; p=0.149$ & $F_{2,16}=0.6 ; p=0.604$ \\
6 - Oct. 1 to 10,2000 & $F_{2,16}=2.1 ; p=0.145$ & $F_{2,16}=3.4 ; p=0.050$ & $F_{2,16}=1.7 ; p=0.203$ \\
7 - Oct. 11 to 20,2000 & $F_{2,16}=3.8 ; p=0.037$ & $F_{2,16}=1.9 ; p=0.172$ & $F_{2,16}=1.1 ; p=0.364$ \\
8 - Oct. 21 to 31,2000 & $F_{2,16}=4.7 ; p=0.020$ & $F_{2,16}=4.2 ; p=0.026$ & $F_{2,16}=1.4 ; p=0.279$ \\
9 - Nov. 1 to 10,2000 & $F_{2,16}=3.4 ; p=0.048$ & $F_{2,16}=2.9 ; p=0.074$ & $F_{2,16}=1.1 ; p=0.365$ \\
10 - Nov. 11 to 20,2000 & $F_{2,16}=1.9 ; p=0.170$ & $F_{2,16}=0.6 ; p=0.588$ & $F_{2,16}=0.79 ; p=0.519$ \\
11 - Nov. 21 to 30,2000 & $F_{2,16}=1.8 ; p=0.185$ & $F_{2,16}=0.6 ; p=0.588$ & $F_{2,16}=0.9 ; p=0.431$ \\
12 - Dec. 1 to 10,2000 & $F_{2,16}=1.8 ; p=0.181$ & $F_{2,16}=1 ; p=0.413$ & $F_{2,16}=1.4 ; p=0.274$ \\
13 - Dec. 11 to 20,2000 & $F_{2,16}=1.2 ; p=0.348$ & $F_{2,16}=1.6 ; p=0.223$ & $F_{2,16}=0.4 ; p=0.735$ \\
14 - Dec. 21 to 31,2000 & $F_{2,16}=0.7 ; p=0.551$ & $F_{2,16}=1 ; p=0.407$ & $F_{2,16}=0.1 ; p=0.946$ \\
15 - Jan. 1 to 10,2001 & $F_{2,16}=0.7 ; p=0.529$ & $F_{2,16}=2.5 ; p=0.143$ & $F_{2,16}=0.2 ; p=0.881$ \\
16 - Jan. 11 to 20,2001 & $F_{2,16}=1.2 ; p=0.321$ & $F_{2,16}=0.7 ; p=0.546$ & $F_{2,16}=0.6 ; p=0.609$ \\
17 - Jan. 21 to 31,2001 & $F_{2,16}=1.1 ; p=0.366$ & & $F_{2,16}=0.8 ; p=0.514$ \\
\hline
\end{tabular}


show different $T_{\mathrm{b}}$ than males. However, Verdade et al. (2006) have reported a consistent individual variation of space use by the broad-snouted caiman in captivity, possibly due to the lack of intermale competition for territories as those captive groups had single males. Nevertheless, the difference in $T_{\mathrm{b}}$ between males and females in this study may be due to their distinct reproductive biology. In addition, in this study, we found no relationship between body mass and snout-vent length and $T_{\mathrm{b}}$. Similar patterns have been previously described for crocodilians (Diefenbach 1975a; Downs et al. 2008; Smith 1979). However, future studies should include a broader range of body sizes, as well as different periods of the year.

The period during which the $T_{\mathrm{b}}$ of the fertile females (i.e., those that laid fertile eggs) was higher than that of the non-fertile ones (i.e., those that laid infertile eggs) apparently coincided with the ovulation period. Changes in $T_{\mathrm{b}}$ due to the reproductive condition of females are relatively well documented in reptiles (Blazquez 1995; Charland 1995; Daut and Andrews 1993; Rock et al. 2000; Rosen 1991; Tu and Hutchison 1994). It is likely that the temperature increase during gestation results in an increase of the rate of embryonic development (Shine 1983).

Social behavior significantly affects crocodilians' thermoregulation (Seebacher et al. 1999). The social hierarchy of females may have influenced the results of the present study because it directly affects reproductive success (Joanen and McNease 1989; Lang 1987, 1989; Verdade 1992b). Social dominance can be related to the use of habitat and available resources (Alcock 1993; Krebs 1985; Krebs and Davis 1991; Verdade 1992b). Cardeilhac $(1989,1990)$ states that competition for areas suitable for sunbathing during the pre-ovulation period can affect the gonadal development of females with a low hierarchical position, preventing them from entering ovulation or even achieving the minimum follicular development required for ovulation.

The behavioral change associated with nesting and nest protection by the reproductive females may have influenced the present results, because possible disputes over nesting sites may affect the thermoregulatory behavior of the subordinate animals. These animals could be excluded from the best nesting habitats, which could also restrict their basking sites, thus affecting their thermoregulatory behavior (Verdade 1992b). Agonistic displays by adults, especially during the reproductive period, are common in crocodilians (Ayarzaguena 1983; Garrick and Lang 1977; Lang 1987; Verdade 1992b, 1999; Vliet 1989). Agonistic interactions among females involving thermoregulatory behavior were also observed during this study.

The animals that died from bite wounds (possibly associated with infectious diseases) presented a higher minimum $T_{\mathrm{b}}$ than healthy animals during a certain period.
Behavioral fever resulting from infections has been previously reported for diverse ectothermic taxa, including turtles (do Amaral et al. 2002), lizards (Firth et al. 1980; Merchant et al. 2008; Ortega et al. 1991), and crocodilians (Lang 1987; Merchant et al. 2007). American alligators in controlled experiments exhibited 2 days of fever after inoculation with an infectious agent. The increase in $T_{\mathrm{b}}$ relative to that of a control group was $2.6^{\circ} \mathrm{C}$ on the first day and $3.5^{\circ} \mathrm{C}$ on the second day (Merchant et al. 2007). Fever is a component of the physiological defense of the host against invading agents (microbial or non-microbial) recognized as foreign bodies by the host's immune system (Zeisberger 1999). In the present study, the individuals suffering from infections appeared to seek hotter areas for sunbathing.

\section{Conclusions}

The results of this study show that sex, reproductive status, and health condition can affect the $T_{\mathrm{b}}$ of adult broadsnouted caiman in captivity. Crocodilians are intensively managed for sustainable use of their meat and leather. Future studies should focus on the relationships between thermoregulatory behavior and management both in captivity (e.g., the design of the captive facilities; see Verdade and Piña 2006) and in the wild (e.g., the influence of hunting pressure on social behavior; see Verdade 1996), as environmental anthropic pressures can affect individuals' growth rate and reproductive performance.

\section{Competing interests}

The authors declare that they have no competing interests.

\section{Authors' contributions}

$\angle A B B$ carried out the experiments and wrote the preliminary draft of this manuscript. LMV, TSM, AM, and CIP gave advice in the statistical analysis and revised the manuscript. LMV carried out the design and coordination of the study. All authors have approved the final version of the manuscript.

\section{Acknowledgements}

This study has been granted by São Paulo Science Foundation (FAPESP Proc. No. 2000/00597-7). LMV and AM have research productivity scholarships from the National Council for Scientific and Technological Development (CNPq).

\section{Author details}

'Laboratório de Ecologia Isotópica, Centro de Energia Nuclear na Agricultura, Universidade de São Paulo, Caixa Postal 96, Piracicaba, São Paulo 13416-000, Brazil. ${ }^{2}$ Universidade Federal do Tocantins, ALCNO 14, Av. NS 15, s/n, Bloco III, sala 15A, Palmas, Tocantins 77010-970, Brazil. ${ }^{3}$ Proyecto Yacaré,

CICyTTP-CONICET Fac. CyT-UAdER/FCAI-UNER, Dr. Matteri y España,

Diamante, Entre Ríos 3105, Argentina.

Received: 13 September 2013 Accepted: 16 January 2014

Published: 4 February 2014

\section{References}

Alcock J (1993) Animal behavior. Sinauer, Sunderland

Allstead J, Lang JW (1995) Sexual dimorphism in the genital morphology of young American alligators, Alligator mississippiensis. Herpetologica 51:314-325

Asa CS, London GD, Goellner RR, Hasskell N, Roberts G, Wilson C (1998) Thermoregulatory behavior of captive American alligators (Alligator mississippiensis). J Herpetol 32:191-197 
Ayarzaguena J (1983) Ecologia del caiman de anteojos o baba (Caiman crocodilus L.) en los Ilanos de Apure (Venezuela). Don Acta Verteb 3:1-136

Blazquez MC (1995) Body temperature, activity patterns and movements by gravid and non-gravid females of Malpolon monspessulam. J Herpetol 29:264-266

Brandt LA, Mazzotti FJ (1990) The behavior of juvenile Alligator mississippiensis and Caiman crocodilus exposed to low temperature. Copeia 1990:867-871

Bustard H (1975) Captive breeding of crocodiles. In: Martin RD (ed) Breeding endangered species in captivity. Academic, London

Bustard H (1980) Maternal care in the gharial, Gavialis gangeticus (Gmelin). $\mathrm{Br} J$ Herpetol 6:63-64

Cardeilhac P (1989) Husbandry and preventative medicine practices that increase reproductive efficiency of breeding colonies of alligators. Florida Department of Agriculture and Consumer Services, Tallahassee

Cardeilhac P (1990) Husbandry and preventative medicine practices that increase reproductive efficiency of breeding colonies of alligators (II). Florida Department of Agriculture and Consumer Services, Tallahassee

Charland MB (1995) Thermal consequence of reptilian viviparity: thermoregulation in gravid and nongravid snakes (Thamnophis). J Herpetol 29:383-390

Coulson RA, Hernandez T (1983) Alligator metabolism: studies on chemical reactions in vivo. Pergamon, London

Diefenbach COC (1975a) Thermal preferences and thermoregulation in Caiman crocodilus. Copeia 1975:530-540

Diefenbach COC (1975b) Gastric function in Caiman crocodilus (Crocodylia: Reptilia) - I. Rate of gastric digestion and gastric motility as a function of temperature. Comp Biochem Physiol 51:259-265

Daut EF, Andrews RM (1993) The effect of pregnancy on selected body temperatures of the viviparous lizard Chalcides ocellatus. J Herpetol 27:6-13

do Amaral JP, Marvin GA, Hutchison VH (2002) The influence of bacterial lipopolysaccharide on the thermoregulation of the box turtle Terrapene carolina. Physiol Biochem Zool 75:273-282

Downs CT, Greaver C, Taylor R (2008) Body temperature and basking behaviour of Nile crocodiles (Crocodylus niloticus) during winter. J Therm Biol 33:185-192

Fincatti CR, Verdade LM (2002) Variação térmica microclimática em estufa plástica e sua aplicação para a manutenção de filhotes de jacarés. In: Verdade LM Larriera A (ed) Conservação e manejo de jacarés e crocodilos da América Latina. C.N. Editoria, Piracicaba

Firth BT, Ralph CL, Boardman TJ (1980) Independent effects of the pineal and a bacterial pyrogen in behavioural thermoregulation in lizards. Nature 285:399-400

Fish FE, Cosgrove LA (1987) Behavioral thermoregulation of small American alligators in water: postural changes in relation to the thermal environment. Copeia 1987:804-807

Garrick LD, Lang W (1977) Social signals and behaviors of adult alligators and crocodiles. Am Zool 17:225-239

Goodwin TM, Marion WR (1979) Seasonal activity ranges and habitat preferences of adult alligators in a north-central Florida lake. J Herpetol 13:157-164

Hunt RH (1987) Nest excavation and neonate transport in wild Alligator mississippiensis. J Herpetol 21:348-350

Joanen T, McNease L (1989) Ecology and physiology of nesting and early development of the American alligator. Am Zool 29:987-998

Krebs CJ (1985) Ecology: the experimental analysis of distribution and abundance. Harper Collins, New York

Krebs JR, Davis NB (1991) An introduction to behavioural ecology. Blackwell, London

Lang JW (1987) Crocodilian behaviour: implications for management. In: Webb GJW, Manolis SC, Whitehead PJ (ed) Wildlife management: crocodile and alligators. Surrey Beatty, Chipping Norton

Lang JW (1989) Social behavior. In: Ross CA (ed) Crocodiles and alligators. Golden, Silverwater

Larriera A, Aguinaga M, Barco D (1990) Observaciones sobre el crescimiento de Caiman latirostris (Daudin, 1802), a diferentes temperaturas (Crocodylia: Alligatoridae). Rev Arg Prod An 1:115-117

Merchant M, Fleury L, Rutherford R, Paulissen M (2008) Effects of bacterial lipopolysaccharide on thermoregulation in green anole lizards (Anolis carolinensis). Vet Immunol Immunopathol 125:176-181

Merchant M, Williams S, Trosclair PL, Elsey RM, Mills K (2007) Febrile response to infection in the American alligator (Alligator mississippiensis). Comp Biochem Physiol 148:921-925
Merwe NJ, Kotze SH (1993) The topography of the thoracic and abdominal organs of Nile crocodile (Crocodylus niloticus). J Veter Resear 60:210-222

Minitab (2000) Minitab for Windows Release 13. Minitab, State College

Miranda MP, Moraes GV, Martins EN, Maia LC (1999) Incubação artificial a $28^{\circ} \mathrm{C}$ e crescimento inicial de jacaré do pantanal (Caiman crocodilus yacare) em diferentes temperaturas. Ac Scient 21:613-617

Molina FB, Sajdak RA (1993) Observações sobre a preferência térmica e o comportamento de termorregulação no jacaré-de-papo-amarelo, Caiman latirostris, em cativeiro: variações ontogenéticas e algumas comparações com outras espécies de jacarés neotropicais. In: Verdade LM, Packer IU, Rocha MB, Molina FB, Duarte PG, Lula LABM (ed) Anais do $3^{\circ}$ Workshop sobre Conservação e Manejo do Jacaré-de-papo-amarelo. ESALQ, Departamento de Zootecnia, Piracicaba

Ortega CE, Stranc DS, Casal MP, Halman GM, Muchlinski AE (1991) A positive fever response in Agama agama and Sceloporus orcutti (Reptilia: Agamidae and iguanidae). J Comp Physiol B 161:377-381

Pough FH, Andrews RM, Cadle JE, Crump ML, Savistsky AH, Wells KD (2003) Herpetology. Prentice Hall, Englewood Cliffs

Rock J, Andrews RM, Cree A (2000) Effects of reproductive condition, season, and site on selected temperatures of a viviparous gecko. Physiol Biochem Zool 73:344-355

Rosen PC (1991) Comparative field study of thermal preferenda in garter snakes (Thamnophis). J Herpetol 25:301-312

Sajdak RA, Molina FB (1992) Observações preliminares sobre a preferência térmica e o comportamento de termorregulação no jacaré-de-papo-amarelo, Caiman latirostris, em cativeiro (Reptilia, Crocodylia, Alligatoridae). In: Anais do Workshop sobre Conservação e Manejo do Jacaré-de-papo-amarelo (Caiman latirostris). ESALQ, Departamento de Zootecnia, Piracicaba

Sarkis-Gonçalves F (2000) Uso de descartes de produção animal na alimentação de jacaré-de-papo-amarelo (Caiman latirostris) em cativeiro. Master dissertation, Escola Superior de Agricultura "Luiz de Queiroz", Universidade de São Paulo, Piracicaba, Brazil

Seebacher F, Franklin CE (2005) Physiological mechanisms of thermoregulation in reptiles: a review. J Comp Physiol B 175:533-541

Seebacher F, Grigg GC, Beard LA (1999) Crocodiles as dinosaurs: behavioural thermoregulation in very large ectotherms leads to high and stable body temperatures. J Exp Biol 202:77-86

Seidel MR (1979) The osteoderms of the American alligator and their functional significance. Herpetologica 35:375-380

Shine R (1983) Reptilian viviparity in cold climates: testing the assumptions of an evolutionary hypothesis. Oecologia 57:397-405

Silva RG (2000) Introdução à bioclimatologia animal. Nobel, São Paulo

Smith EN (1979) Behavioral and physiological thermoregulation of crocodilians. Am Zool 19:239-247

Smith EN, Robertson S, Davies DG (1978) Cutaneous blood flow during heating and cooling in the American alligator. Am J Physiol 235:160-167

Staton MA, Edward HM, Jr, Brisbin IL, Jr, Joanen T, McNease L (1992) The influence of the environmental temperature and dietary factors on utilization of dietary energy and protein in purified diets by alligators, Alligator mississippiensis (Daudin). Aquaculture 107:369-381

Troiano JC (1991) Manejo sanitario de reptiles en cautiveiro. Editorial Prensa Veterinaria Argentina, Buenos Aires

Tu M, Hutchison VH (1994) Influence of pregnancy on thermoregulation of water snakes (Nerodia rhumbifera). J Therm Biol 19:255-259

Verdade LM (1992a) Manejo reprodutivo do jacaré-de-papo-amarelo, Caiman latirostris (Daudin, 1802), em cativeiro. Master dissertation, Escola Superior de Agricultura "Luiz de Queiroz", Universidade de São Paulo, Brazil

Verdade LM (1992b) Agonistic social behavior of broad-nosed caiman (Caiman latirostris) in captivity: implications to reproductive management. In: Working meeting of the Crocodile Specialist Group. IUCN - The World Conservation Union, Gland

Verdade LM (1996) The influence of hunting pressure on the social behavior of vertebrates. Rev Bras Biol 56:1-13

Verdade LM (1999) Caiman latirostris (broad-snouted caiman) behavior. Herp Rev 30:38-39

Verdade LM, Kassouf-Perina ES (1993) Studbook regional do jacaré-de-papo-amarelo (Caiman latirostris) - 1992/1993. Sociedade de Zoológicos do Brasil, Sorocaba

Verdade LM, Piña Cl (2006) Caiman latirostris. Catalog of American amphibians and reptiles, vol 833. Society for the Study of Amphibians and Reptiles, Athens, pp 1-21 
Verdade LM, Lavorenti A, Packer IU (1993) Manejo reprodutivo do jacaré-depapo-amarelo (Caiman latirostris) em cativeiro. In: Verdade LM, Packer IU, Rocha MB, Molina FB, Duarte PG, Lula LABM (ed) Anais do $3^{\circ}$ Workshop sobre Conservação e Manejo do Jacaré-de-papo-amarelo. ESALQ, Departamento de Zootecnia, Piracicaba

Verdade LM, Packer IU, Michelotti F, Rangel MC (1994) Thermoregulatory behavior of broad-snouted caiman (Caiman latirostris) under different thermal regimes. In: Larriera A, Imhof A, von Finck MC, Costa AL, Tourn SC (ed) Memorias del IV Workshop sobre Conservación y Manejo del Yacare Overo (Caiman latirostris). Fundación Banco Bica, Santo Tomé, Santa Fé

Verdade LM, Piña Cl, Araújo JLA (2006) Diurnal use of space by captive adult broad-snouted caiman (Caiman latirostris): implications for pen design. Aquaculture 251:333-339

Vianna VO (1995) Efeito da temperatura no desenvolvimento de filhotes de jacaré-de-papo-amarelo, Caiman latirostris (Daudin, 1802), em cativeiro. Master dissertation, Escola Superior de Agricultura "Luiz de Queiroz", Universidade de São Paulo, Brazil

Vianna VO, Lavorenti A, Sarkis-Gonçalves F (1995) Efeito da temperatura no tempo de trânsito gastrointestinal em filhotes de jacaré-de-papo-amarelo, Caiman latirostris (Daudin, 1802) em cativeiro. In: Anais da Reunião Anual da Sociedade Brasileira de Zootecnia. Sociedade Brasileira de Zootecnia, Braśilia

Vliet K (1989) Social displays of the American alligator (Alligator mississippiensis). Am Zool 29:1019-1032

Widholzer FL, Borne B, Tesche T (1986) Breeding the broad-nosed caiman (Caiman latirostris) in captivity. Intern Zoo Yearbook 24:226-230

Zeisberger E (1999) From humoral fever to neuroimmunological control of fever. J Therm Biol 24:287-326

doi:10.1186/1810-522X-53-9

Cite this article as: Bassetti et al:: Thermoregulation in captive broadsnouted caiman (Caiman latirostris). Zoological Studies 2014 53:9.

\section{Submit your manuscript to a SpringerOpen ${ }^{\circ}$ journal and benefit from:}

- Convenient online submission

- Rigorous peer review

- Immediate publication on acceptance

- Open access: articles freely available online

- High visibility within the field

- Retaining the copyright to your article

Submit your next manuscript at $\gg$ springeropen.com 